Arch. Tierz., Dummerstorf 50 (2007) 2, 155-164

Humboldt-Universität zu Berlin, Institute of Animal Sciences, Department of Animal Breeding in the Tropics and Subtropics, Germany

AMANI Z. ABDEL GADER, MOHAMED-KHAIR A. AHMED, LUTFI M.-A. MUSA and KURT J. PETERS

\title{
Milk yield and reproductive performance of Friesian cows under Sudan tropical conditions
}

\begin{abstract}
The data obtained from the dairy herd of the Arab Company for Agricultural Production and Processing (ACAPP) in a semi arid area $40 \mathrm{~km}$ south of Khartoum involved 337 cows with a total of 1049 records from 16 years between 1986 and 2002. The least squares means for age at first calving, calving interval, days open, lactation milk yield, daily milk yield, lactation length and dry period were 29.76 \pm 0.40 months, $433.12 \pm 6.70$ days, $167.79 \pm 7.08$ days, $3475.53 \pm 78.89 \mathrm{~kg}, 12.29 \pm 0.28 \mathrm{~kg}, 294.10 \pm 3.62$ days and $164.08 \pm 6.70$ days, respectively.

The analysis of variance showed that the parity number had significant $(\mathrm{p}<0.05)$ influences on all studied traits, while year-season of calving influenced $(\mathrm{p}<0.05)$ age at first calving, milk yield per lactation and daily milk yield. The sire of cow influenced $(\mathrm{p}<0.05)$ lactation yield, daily yield, lactation length and days open. The effects of linear and quadratic regressions of both lactation yield and daily yield on length of lactation were also highly significant $(\mathrm{p}<0.01)$.

Heritability estimates of age at first calving, calving interval, milk yield per lactation, daily milk yield, lactation length and dry period were generally low $(0.098 \pm 0.104,0.047 \pm 0.046,0.130 \pm 0.042,0.123 \pm 0.041,0.172 \pm 0.062$ and $0.044 \pm 0.031$, respectively) except the heritability of days open which was $0.51 \pm 0.37$.

The productivity of the herd in this study which averaged $12.3 \mathrm{~kg} / \mathrm{cow} /$ day was much lower than the expected productivity of Holstein Friesian cows, which reflects the negative impact of the prevalent environment in the Sudan.

More records and economic data are required to examine the economic feasibility of raising pure Friesians under Sudan conditions.
\end{abstract}

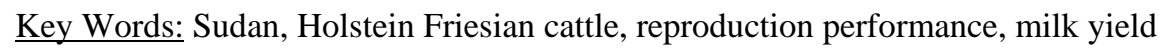

\section{Zusammenfassung}

Titel der Arbeit: Milchleistung und Fruchtbarkeit von Holstein-Friesian-Kühen im Sudan

Leistungsdaten von 337 Holstein-Friesian-Kühen mit insgesamt 1049 Leistungsangaben aus 16 Jahren (1986 2002) konnten für eine Bewertung des Leistungsgeschehens herangezogen werden. Das Alter bei Erstabkalbung, Kalbeintervall, Service, Laktationsmilchleistung, tägliche Milchleistung, Laktationslänge und Trockenperiode waren 30 Monate, $433 \pm 6$ Tage, $168 \pm 7$ Tage, $3475 \pm 79$ kg, $12 \pm$ 0,3 kg, $294 \pm 4$ Tage and $164 \pm 7$ Tage. Die Laktationsnummer hat einen signifikanten Effekt auf alle geprüften Merkmale, während Jahr/Saison der Kalbung sich signifikant auf das Erstkalbealter, die Laktationsleistung und die tägliche Milchleistung auswirkte. Ein signifikanter Bulleneffekt konnte für die Laktationsleistung und tägliche Leistung sowie die Laktationslänge und Trockenperiode nachgewiesen werden. Zwischen den Parametern der Laktationsleistung und der Länge der Laktation lag eine hoch signifikante quadratische Beziehung vor. Die ermittelten Heritabilitätsparameter für Alter bei Erstkalbung, Kalbeintervall, Laktationsmilchleistung, tägliche Milchleistung, Laktationslänge und Trockenperiode waren niedrig und hatten hohe Standardfehler $(0,098 \pm 0,104 ; 0,047 \pm 0,046 ; 0,130 \pm 0,042 ; 0,123 \pm$ $0,041 ; 0,172 \pm 0,062$ und 0,044 $\pm 0,031)$. Nur für die Zwischentragezeit konnte ein höherer Heritabilitätswert von $0,51 \pm 0,37$ ermittelt werden.

Die gezeigte Leistung der Holstein-Friesian-Kühe mit 3475 kg Milch pro Laktation oder 12,3 kg Milch pro Tier und Tag liegt weiter unter dem Leistungsvermögen und reflektiert negative Einflüsse der natürlichen Standortverhältnisse und Produktionsbedingungen im Sudan. Weitere Analysen zur Produktivität und der Produktionsökonomik sind erforderlich, um die Wirtschaftlichkeit der Haltung von Holstein-Friesian-Kühen im Sudan zu bewerten.

Schlüsselwörter: Sudan, Rinder, Holstein Friesian, Fruchtbarkeit, Milchleistung 


\section{Introduction}

The Sudan lies entirely within the tropics between latitudes $22^{\circ}$ and $4^{\circ} \mathrm{N}$. Cattle are the main source of milk and meat in the Sudan and despite the huge numbers of cattle in the country (36 million heads according to AOAD, 2004) the Sudan has to import an appreciable proportion of its milk requirements. Although highly adapted to the local environment and to the needs of stockholders the indigenous types of cattle are mostly poor milk producers, but there are some promising local types (SAEED et al., 1987; MUSA et al., 2005). The need for a quick solution to the problem of the deficit in milk production has led to the importation of high producing European dairy breeds. During the last three decades the Sudan has seen some major importations of exotic dairy cattle. In 1984-85 the Arab Company for Agricultural Production and Processing (ACAPP) imported 1000 Friesian heifers-in-calf from West Germany. In the same period Khartoum Company for milk products imported 500 heifers and the Islamic development Company imported 750 heifers in the period 1986-1989 and since that time the importation of Friesian cows has become widespread. In addition artificial insemination with imported Friesian semen is widely used in farms close to urban centres and even in some rural areas. In the last few years some of the ventures that were based on imported Friesian cows started to fail. Temperate breeds suffer from inadequacy of feeding in both quantity and quality, inadequate management and the prevalence of parasites and diseases. High costs of feeding, veterinary care, the special housing needs of exotic cattle and the constraints of the local physical and biotic environment probably contributed to the demise of these ventures. Efforts to investigate the causes of failure of these ventures have been hindered by the lack of access to production records. In this paper we attempt to study the performance of Friesian cows of the ACAPP herd whose dairy activities ceased in 2002, the object is to study the impact of genetic and environmental factors on the performance of Friesian cattle under the semi arid environment of Khartoum State.

\section{Materials and Methods}

The dairy farm of the Arab Company for Agricultural Production and Processing (ACAPP) is located $40 \mathrm{~km}$ south of Khartoum in a semi arid area with an annual rainfall of $167 \mathrm{~mm}$. Most of the rainfall (about $70 \mathrm{~mm}$ ) is during the wet summer season that extends from July to September. Temperature in the area is high with an annual mean average of $30.7^{\circ} \mathrm{C}$ and extremes of over $45^{\circ} \mathrm{C}$. The hottest months are June and July with a mean average temperature of $35.5^{\circ} \mathrm{C}$. The lowest temperatures are usually recorded in January with an average temperature of $24.6^{\circ} \mathrm{C}$. Humidity is generally low which makes the high temperatures more tolerable.

Animals were kept in shaded pens with concrete floors throughout the day and were allowed to rest in a fenced unshaded yard during the cool hours of night. The buildings are essentially open with low walls and shutters on the south western side to protect against dust storms. Groups of 48 cows were housed together in a single pen. Lactating cows, dry cows, cows in late pregnancy, stud males and calves were penned separately. The animals were fed on green fodders or dry roughages and a concentrate mix, the latter offered twice daily. The concentrate mix usually consisted of all or some of the following ingredients: Cakes, wheat bran, sorghum grain, molasses, sorghum gluten, salt and lime. There were annual and seasonal fluctuations in the quality and availability of feedstuffs. Cows were machine milked twice daily in a 16x2 
milking parlour supplied with cooling and storage facilities to serve 500 cows. Artificial insemination using imported semen of proven bulls was used. All animals in the farm were regularly vaccinated against endemic diseases such as rinderpest, anthrax and foot and mouth disease. Spraying with acaricides for the control of ticks was done twice monthly.

Data analysis:

The data obtained from the ACAPP herd involved 337 cows with a total of 1049 records. The data covered 16 years between 1986 and 2002. The traits studied were milk yield per lactation, daily milk yield, lactation length and dry period. The data was analyzed using Harvey’s (1990) Least Squares and Maximum likelihood programme. The following statistical models were applied.

\section{Model (1)}

Analysis of age at first calving:

$Y_{i j}=\mu+S_{i}+A_{j}+E_{i j}$

Where

$\mathrm{Y}_{\mathrm{ij}}=$ the $\mathrm{ij}^{\text {th }}$ observation of the trait in question

$\mu=$ the overall mean.

$S_{i}=$ the random effect of the $j^{\text {th }}$ sire $(j=1,68)$

$A_{j}=$ the $i^{\text {th }}$ year-season of calving ( $\left.i=1-9\right)$

$E_{\mathrm{ij}}=$ residual error

Model (2)

Analysis of calving interval, days open and dry period:

$\mathrm{Y}_{\mathrm{ijk}}=\mu+\mathrm{S}_{\mathrm{i}}+\mathrm{A}_{\mathrm{j}}+\mathrm{P}_{\mathrm{k}}+\mathrm{b}_{1} \mathrm{D}+\mathrm{E}_{\mathrm{ijk}}$

Where:

$\mathrm{P}_{\mathrm{k}}=$ the $\mathrm{k}^{\text {th }}$ effect of the parity number $(\mathrm{k}=1,4)$

$\mathrm{b}_{1}=$ linear regression coefficient

$\mathrm{D}=$ the deviation of lactation length from its mean

The rest of the terms are as in model (1) above

Model (3)

Analysis of milk yield per lactation and daily milk yield:

$Y_{i j k}=\mu+S_{i}+A_{j}+P_{k}+b_{1} D+b_{2} D^{2}+E_{i j k}$

Where:

$\mathrm{b}_{2}=$ quadratic regressions coefficient

The rest of the terms are as in models (1 and 2) above

Model (4)

Analysis of lactation length:

$\mathrm{Y}_{\mathrm{ijk}}=\mu+\mathrm{S}_{\mathrm{i}}+\mathrm{A}_{\mathrm{j}}+\mathrm{P}_{\mathrm{k}}+\mathrm{b}_{1} \mathrm{D}+\mathrm{E}_{\mathrm{ijk}}$

Where:

$\mathrm{D}=$ daily milk yield

The rest of the terms are as in model (1, 2 and 3) above.

The heritabilities were estimated by paternal half-sib variance analysis as described by BECKER (1975). Differences between means were tested using Duncan's Multiple Range Test (DMRT). 


\section{Results}

Tables 1, 2 and 3 show the analysis of variance performed on the ACAPP data using a mixed model. The results indicated that parity number had significant $(p<0.05)$ influences on all studied traits, while year-season of calving influenced $(\mathrm{p}<0.05)$ age at first calving, milk yield per lactation and daily milk yield. The sire of cow influenced $(p<0.05)$ lactation yield, daily yield, lactation length and days open. The effects of linear and quadratic regressions of both lactation yield and daily yield on length of lactation were also highly significant $(\mathrm{p}<0.01)$. The results also showed that linear and

Table 1

Least squares means and standard errors of age at first calving (LSQ-Mittelwert der Erstkalbealter bei Holstein Friesian)

\begin{tabular}{lcc}
\hline Items & $\mathrm{n}$ & $\begin{array}{c}\text { Age at } 1^{\text {st }} \text { calving } \\
\text { L.S.M } \pm \text { S.E (months) }\end{array}$ \\
\hline Overall mean & 300 & $29.76 \pm 0.40$ \\
Sire & & $\mathrm{n} . \mathrm{s}$ \\
Calving year-season & & $25.44 \pm 1.34$ \\
Winter 1986-1989 & 57 & $27.03 \pm 1.34$ \\
Dry summer & 71 & $27.88 \pm 1.46$ \\
Wet summer & 34 & $30.66 \pm 1.38$ \\
Winter 1990-1993 & 41 & $33.82 \pm 1.46$ \\
Dry summer & 23 & $31.59 \pm 1.41$ \\
Wet summer & 46 & $32.01 \pm 2.79$ \\
Winter 1994-2002 & 9 & $29.71 \pm 2.76$ \\
Dry summer & 11 & $29.71 \pm 2.76$ \\
Wet summer & 8 & $14.20 \%$ \\
Coefficient of variation & & .
\end{tabular}

L.S.M = least squares mean $\quad$ S.E = standard error $\quad \mathrm{n}$ = total number of observations; Means without a common superscript differ significantly $(\mathrm{P}<0.05)$; (Winter $=$ November - February, Dry summer $=$ March - June \& Wet summer $=$ July - October $)$

$* *=\mathrm{P}<0.001 \quad$ n.s $=$ not significant

Table 2

Least squares means and standard errors of calving interval, dry period and days open of Holstein Friesian cows (LSQ-Mittelwerte der Zwischenkalbezeit, Trockenstehzeiten und Zwischentragezeit bei Holstein Friesian)

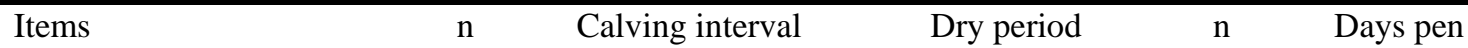

(784) (874)

\begin{tabular}{|c|c|c|c|c|c|}
\hline & & & L.S.M. \pm S.E. ( & & \\
\hline Overall mean & & $433.12 \pm 6.70$ & $164.08 \pm 6.70$ & & $167.79 \pm 7.08$ \\
\hline Sire & & n.s & n.s & & $*$ \\
\hline Parities & & $*$ & $*$ & & $* *$ \\
\hline First parity & 315 & $422.86 \pm 8.08^{\mathrm{a}}$ & $153.81 \pm 8.08^{\mathrm{a}}$ & 322 & $141.42 \pm 8.81^{\mathrm{a}}$ \\
\hline Second parity & 291 & $430.53 \pm 8.31^{\mathrm{a}}$ & $161.48 \pm 8.31^{\mathrm{ab}}$ & 295 & $150.71 \pm 8.98^{\mathrm{a}}$ \\
\hline Third parity & 178 & $445.97 \pm 9.67^{b}$ & $176.93 \pm 9.67^{b}$ & 193 & $184.31 \pm 10.11^{\mathrm{ab}}$ \\
\hline Fourth parity & & - & - & 64 & $194.70 \pm 15.10^{b}$ \\
\hline Calving year-season & & n.s & n.s & & n.s \\
\hline Winter 1986-1989 & 138 & $431.69 \pm 16.37$ & $126.64 \pm 16.37$ & 148 & $171.65 \pm 14.59$ \\
\hline Dry summer & 135 & $425.10 \pm 17.05$ & $156.06 \pm 17.05$ & 139 & $185.00 \pm 15.34$ \\
\hline Wet summer & 91 & $435.89 \pm 18.23$ & $166.85 \pm 18.23$ & 92 & $176.81 \pm 16.88$ \\
\hline Winter $\quad 1990-1993$ & 147 & $412.23 \pm 14.83$ & $143.19 \pm 14.83$ & 162 & $162.43 \pm 12.32$ \\
\hline Dry summer & 63 & $448.52 \pm 17.92$ & $179.48 \pm 17.92$ & 68 & $198.84 \pm 16.03$ \\
\hline Wet summer & 150 & $414.86 \pm 14.83$ & $145.82 \pm 14.83$ & 175 & $171.85 \pm 12.02$ \\
\hline Winter 1994-2002 & 25 & $436.59 \pm 31.45$ & $167.55 \pm 31.45$ & 29 & $144.52 \pm 25.46$ \\
\hline Dry summer & 16 & $478.12 \pm 36.13$ & $209.08 \pm 36.13$ & 28 & $145.68 \pm 27.00$ \\
\hline Wet summer & 19 & $415.05 \pm 32.87$ & $146.01 \pm 32.87$ & 33 & $153.29 \pm 24.19$ \\
\hline $\begin{array}{l}\text { Linear regression on } \\
\text { lactation length }\end{array}$ & & $0.494 \pm 0.616^{* *}$ & $-0.506 \pm 0.062 * *$ & & $0.181 \pm 0.059 * *$ \\
\hline Coefficient of variation & & $23.79 \%$ & $65.09 \%$ & & $65.01 \%$ \\
\hline
\end{tabular}


quadratic regressions of lactation length on average daily milk yield were highly significant $(\mathrm{p}<0.01)$. In addition, the linear regression on lactation length had a significant $(\mathrm{p}<0.001)$ effect on calving interval, dry period and days open.

The estimated least squares means for age at first calving (Table 1) is $29.762 \pm 0.395$ months, with a coefficient of variation of $14.20 \%$. Table 2 presents the least squares means for calving interval, dry period and days open. Calving interval increased from $422.856 \pm 8.081$ in the first parity to $445.970 \pm 9.670$ in the third parity, the latter being significantly different from the first two. There was no clear trend in calving interval across years but the longest calving interval of 478.119 \pm 36.131 was recorded for cows calving in the dry summer of the period 1994-2002. The dry period was $153.81 \pm 8.08$ days after the first parity and 176.93 \pm 9.67 days after the third parity. The longest dry periods across calving year-season were those of cows calving in the dry summer. The overall mean of days open was $167.79 \pm 7.08$ and similar to calving interval, was lowest in the first parity (141.42 \pm 8.81$)$ and highest in the fourth parity (194.70 \pm 15.10$)$. The longest period of days open was recorded for cows calving during the dry summer of 1990-1993.

Table 3

Least squares means and standard error of milk yield per lactation, daily milk yield and lactation length (LSQMittelwerte der Milchleistung und Laktationslänge bei Holstein Friesian)

\begin{tabular}{|c|c|c|c|c|}
\hline \multirow[t]{2}{*}{ Items } & $\begin{array}{c}n \\
(1049)\end{array}$ & Lactation milk yield & Daily milk yield & \multirow{2}{*}{$\begin{array}{c}\text { Lactation length } \\
\text { L.S.M. } \pm \text { S.E. (days) }\end{array}$} \\
\hline & & \multicolumn{2}{|c|}{ L.S.M. \pm S.E. $(\mathrm{kg})$} & \\
\hline Overall mean & & $3475.53 \pm 78.89$ & $12.29 \pm 0.28$ & $294.10 \pm 3.62$ \\
\hline Sire & & $* *$ & $* *$ & $* *$ \\
\hline Parities & & $* *$ & $* *$ & $* *$ \\
\hline First parity & 325 & $3186.69 \pm 93.58^{\mathrm{a}}$ & $11.24 \pm 0.33^{\mathrm{a}}$ & $298.50 \pm 4.68^{\mathrm{a}}$ \\
\hline Second parity & 310 & $3496.30 \pm 93.58^{b}$ & $12.34 \pm 0.33^{b}$ & $298.48 \pm 4.70^{\mathrm{a}}$ \\
\hline Third parity & 277 & $3577.38 \pm 96.79^{c}$ & $12.66 \pm 0.35^{\mathrm{c}}$ & $293.12 \pm 4.87^{\mathrm{ab}}$ \\
\hline Fourth parity & 137 & $3641.73 \pm 114.65^{\mathrm{c}}$ & $12.93 \pm 0.41^{\mathrm{c}}$ & $286.32 \pm 6.23^{b}$ \\
\hline Calving year-season & & $* *$ & $* *$ & n.s \\
\hline Winter $\quad$ 1986-1989 & 156 & $3013.85 \pm 131.43$ & $10.64 \pm 0.47$ & $260.48 \pm 7.35$ \\
\hline Dry summer & 143 & $2881.38 \pm 137.34$ & $10.09 \pm 0.49$ & $260.50 \pm 7.35$ \\
\hline Wet summer & 97 & $3022.19 \pm 149.91$ & $10.58 \pm 0.54$ & $260.83 \pm 7.77$ \\
\hline $1990-1993$ & 225 & $3656.15 \pm 106.40$ & $13.11 \pm 0.38$ & $268.61 \pm 8.66$ \\
\hline Dry summer & 109 & $3771.55 \pm 125.64$ & $13.54 \pm 0.45$ & $283.79 \pm 6.89$ \\
\hline Wet summer & 216 & $3714.23 \pm 106.67$ & $13.16 \pm 0.83$ & $287.67 \pm 5.70$ \\
\hline Winter $\quad$ 1994-2002 & 39 & $3880.94 \pm 203.56$ & $13.85 \pm 0.74$ & $302.72 \pm 11.81$ \\
\hline Dry summer & 30 & $3656.22 \pm 237.89$ & $12.57 \pm 0.86$ & $356.22 \pm 13.42$ \\
\hline Wet summer & 34 & $3641.73 \pm 114.65$ & $13.07 \pm 0.78$ & $339.30 \pm 12.17$ \\
\hline $\begin{array}{l}\text { Linear regression on } \\
\text { lactation length }\end{array}$ & & $13.128 \pm 0.544^{* *}$ & $0.0105 \pm 0.002 * *$ & \\
\hline $\begin{array}{l}\text { Quadratic regression on } \\
\text { lactation length }\end{array}$ & & $-0.019 \pm 0.003^{* *}$ & $-0.0006 \pm 0.00009 * *$ & \\
\hline $\begin{array}{l}\text { Linear regression on daily } \\
\text { milk yield }\end{array}$ & & & & $2.854 \pm 0.532 * *$ \\
\hline $\begin{array}{l}\text { Quadratic regression on } \\
\text { daily milk yield }\end{array}$ & & & & $-0.452 \pm 0.075 * *$ \\
\hline Coefficient of variation & & $30.21 \%$ & $30.44 \%$ & $21.39 \%$ \\
\hline
\end{tabular}

Table 3 shows the least squares means of lactation and daily milk yield and lactation length. The overall average milk yield of the Friesian herd of ACAPP was 
$3475.53 \pm 78.89 \mathrm{~kg}$ in an average lactation length of $294.10 \pm 3.62$ days and the average daily milk yield was $12.29 \pm 0.28 \mathrm{~kg}$. There was a large significant difference between the first and second lactation $(+310 \mathrm{~kg})$ and despite the fact that the maximum milk yield was reached in the fourth lactation it was not significantly different from the mean of the third lactation. There was important variation among calving year seasons and the average milk yield varied from a low of $2881.38 \pm 137.34$ in the dry summer of the period 1986-1989 to a high of $3880.94 \pm 203.56 \mathrm{~kg}$ in the winter of $1995-2002$. Lactation length was highest after the first and second parities (298 days) and was lowest in the fourth parity (286 days).

Table 4

Heritability estimates of studied (Heritabilitäts-Schätzwerte für Merkmale der Holstein Friesian Rinder)

\begin{tabular}{lc}
\hline Trait & $\mathrm{h}^{2} \pm \mathrm{S} . \mathrm{E}$. \\
\hline Age at first calving & $0.098 \pm 0.104$ \\
Calving interval & $0.047 \pm 0.046$ \\
Days open & $0.510 \pm 0.370$ \\
Milk yield & $0.130 \pm 0.042$ \\
Daily milk & $0.123 \pm 0.041$ \\
Lactation length & $0.172 \pm 0.062$ \\
Dry period & $0.044 \pm 0.031$ \\
\hline $\mathrm{h}^{2}=$ heritability estimate & S.E. = standard error
\end{tabular}

Table 4 presents estimates of heritability of the studied traits. Heritability estimates of both milk yield per lactation and daily milk yield were low $(0.130 \pm 0.042$ and $0.123 \pm 0.041$, respectively). Also the heritabilities of the reproductive traits were generally low except for the heritability of days open $(0.51 \pm 0.37)$.

\section{Discussion \\ Reproductive traits \\ Age at first calving was not significantly ( $>0.05$ ) affected by sires indicating that} differences between sires in the rate of maturity of their daughters were not important, but it was significantly affected by year seasons of birth. However, the data set of age at first calving was the smallest among all traits studied (300 records). The average age at first calving in the present study of $29.76 \pm 0.40$ is consistent with other estimates from the arid tropics. CHAGUNDA et al. (1995) and WOLLNY et al. (1998) studied records of 239 and 268 Holstein Friesian cows in Malawi and found that the average age at first calving was 28.0 and 25.6 months, respectively. CHAGUNDA et al. (2004) found that the age at first calving in three herds in Malawi was 33.1 $\pm 0.45,32.6$ \pm 0.45 and $31.5 \pm 0.24$ months. These results are an indication of the limited possibility for intensive heifer rearing under tropical feeding systems.

Calving interval was not affected by sires or year seasons of calving but was significantly $(\mathrm{p}<0.05)$ affected by parity. TAWFIK et al. $(2000)$ reported a significant effect of season and year of calving and parity on calving interval. The least squares mean for calving interval was $433.12 \pm 6.70$ and it increased significantly $(\mathrm{p}<0.05)$ from $422.86 \pm 8.08$ in the first parity to $445.97 \pm 9.67$ in the third parity. Estimates were generally very close to the estimates of EL AMIN et al. (1986) who found that the average calving interval calculated from 4004 records of different grades of $B$. taurus x Butana cattle in the Sudan was 441 days. TAHIR and MAAROF (1988) in Iraq found that 1396 calving interval records were not significantly affected by sire, age at first calving or parity. CHAGUNDA et al. (2004) reported that the second 
calving interval increased from $407 \pm 4.53$ for progeny of sires with low breeding values for milk yield to $446 \pm 14.2$ days for progeny of sires with high breeding values. They indicated that there was an apparent antagonistic relationship between milk yield and reproduction, in contrast with WOLLNY et al. (1998) who did not find a strong relation between the two.

The number of days open was not affected by year seasons of calving ( $>0.05$ ) but was highly significantly affected by parity $(\mathrm{p}<0.05)$. The number of days open increased significantly as parities advanced from $141.42 \pm 8.81$ in the first parity to $194.70 \pm 15.10$ in the fourth parity. JUMA and AL TIKRITI (1990) analyzed data on 272 Brown Swiss and 273 Friesian cows in Iraq and found that the service period in the two breeds was $138.19 \pm 0.04$ and $145.54 \pm 2.85$, respectively. ATIL (2000) found that mean days open for Holstein Friesian in Egypt was 124 \pm 83.7 days.

Heritability estimates of all studied reproductive traits were below $10 \%$ except for days open which had a heritability of $0.51 \pm 0.37$. Our estimate for days open is higher than that obtained by ATIL (2000). The heritability estimate for calving interval agreed well with that of CHAGUNDA (2004) but it is lower than the estimate obtained by TAWFIK et al. (2000). On the other hand, CHAGUNDA (2004) estimated a higher heritability for age at first calving (0.2) compared to our estimate of $0.098 \pm 0.104$, which in any case had only limited value considering the large error term.

\section{Productive traits}

The analysis of variance of milk yield per lactation and daily milk yield revealed a highly significant $(\mathrm{p}<0.001)$ effect of sire, year-season, parity number, and linear and quadratic regressions on lactation length in both characters. These findings agree with the results of MBAP and NGERE (1989) who analyzed Friesian data from Nigeria, ATIL (2000) for Holstein Friesian in Egypt, KUNAKA et at. (2001) for a Friesian population in Zimbabwe, and HERNANDEZ et al. (2002) for Holsteins in Mexico. The variation in milk yield between years and seasons may be due to changes in management and variation in feed quality and quantity. Average milk yield increased with parity number and reached a maximum in the fourth parity.

It is well established that the tropical environment has a negative impact on the expression of the genetic potential of improved European breeds. In this study overall mean milk yield per lactation and daily milk yield were 3475.526 \pm 78.89 and 12.29 $\pm 0.28 \mathrm{~kg}$, respectively. These results are higher than those reported by TADESSE and DESSIE (2003) who analyzed data on Holstein Friesians and their crosses with local zebu cattle in Ethiopia. They obtained estimates of total, annual and daily milk yield, from records of 90 Holstein Friesian cows as $3183 \pm 111,2679 \pm 120$ and $9.43 \pm 0.39 \mathrm{~kg}$, respectively. Also the results are higher than those obtained by HERNANDEZ et al. (2002) who studied records of 351 Holstein cows in Mexico. They reported that the overall means and standard errors for lactation length, milk production and 305 days milk production were $305 \pm 6.4$ days, $2918 \pm 67.6 \mathrm{~kg}$ and $2635 \pm 51.9 \mathrm{~kg}$, respectively. However, our estimates are lower than those of GYAWU et al. (1990) for 305 day milk yield of Holsteins in Ghana. AHMED et al. (1996) obtained higher estimates for the milk yield of imported and locally born Holsteins in Libya. The latter was an analysis on data obtained from a herd situated in the eastern high altitude coastal region of Libya where temperatures are moderate year round. In Egypt KHATTAB et al. (2005) analyzed 2095 records of Friesian cattle and found that milk yield in the first 
five parities was $4320 \pm 53,5349 \pm 53,4984 \pm 58,4868 \pm 59$ and $4389 \pm 85 \mathrm{~kg}$, respectively. OJANGO and POLLOTT (2002) studied the relationship between Holstein bull breeding values for milk yield derived in the United Kingdom and Kenya to estimate the magnitude of any genotype by environment interaction. They reported a difference in genetic variance between the two countries, with the heritability for first lactation 305 days milk yield being $0.45 \pm 0.02$ in UK and $0.26 \pm 0.06$ in Kenya and that the genetic correlation between first lactation milk yield in the two countries was $0.49 \pm$ 0.06, implying a genotype by environment interaction in milk yield. Also they estimated the relative rate of response in milk yield in Kenya based on UK breeding values to be $44 \%$ of the rate expected in the UK. MOHSEN et al. (2000) used original data of 774 first lactation records of daughters of 124 sires of Friesian herds in Egypt and 9219 first lactation records of daughters of 679 sires of Friesian herds in Germany to estimate genetic and phenotypic trends of 305-day milk yield (305-dMY), lactation period (LP) and calving interval (CI). Annual genetic change was $112.99 \mathrm{~kg},-0.92$ day and 1.78 day for 305-dMY, LP and CI, respectively for Friesian cows in Egypt and was $200.38 \mathrm{~kg}, 0.12$ day and -1.05 day for 305-dMY, LP and CI, respectively for Friesian cows in Germany. For the same set of traits they found that annual phenotypic trend was $48.00 \mathrm{~kg},-1.66$ day and -1.82 day for Friesian cows in Egypt and was $104.00 \mathrm{~kg}, 0.17$ day and 0.78 day, for Friesian cows in Germany.

The coefficients of variation for milk yield in this study amounted to $30.21 \%$ and 30.44 , respectively. This is higher than the value commonly accepted for the coefficient of variation of milk yield (14-20\%). The higher value obtained in this study indicates firstly, more variable production and management conditions and secondly, considerable scope for improvement.

General production problems

The productivity of the herd in this study which averaged $12.3 \mathrm{~kg} / \mathrm{cow} / \mathrm{day}$ was much lower than the expected productivity of Holstein Friesian cows. The cost of maintaining pure Friesians under the tropical conditions of the Sudan is high. They require specially designed pens to minimize direct exposure to the sun and even so signs of heat stress are obvious during the summer months when temperature may exceed $45^{\circ} \mathrm{C}$. In addition, feed requirements, vaccination and health costs of pure Friesians are much higher compared to those of local or crossbred cows. The combined effect of these factors was probably the cause of the termination of the venture and the sale of the herd in 2002. The company that took over the herd in 2002 also sold out in 2006 and the herd was dispersed. Access to more records and economic data might allow a more thorough examination of the performance of pure Friesians under Sudan conditions. However, it is important to investigate the economic feasibility of raising Holstein Friesian in the semi intensive sector in peri urban areas.

The current study had confirmed that Friesian heifers reared under Sudanese farm condition have age at first calving of almost 30 months indicating a much lower rearing intensity than that in temperate dairy systems.

Performance levels for milk yield and lactation length are comparable with other results for Friesian herds in tropical countries, but far below the genetic ability of the breed.

The environmental stress is most evident in reproduction performance traits, which are well below the biological optimum and deteriorate with increasing age. 
Days open of more than 6 months for cows that do get pregnant and the continuous reduction in numbers of cows from $2^{\text {nd }}$ to $3^{\text {rd }}$ and especially $4^{\text {th }}$ lactation clearly demonstrate the problem of sustainable milk production with Holstein Friesian cows under conditions which do not meet the feeding and husbandry demands of these cows.

\section{References}

ABUBAKAR, B.Y.; MCDOWELL, R.E.; VAN VLECK, L.D.:

Genetic Evaluation of Holsteins in Columbia. Journal of Dairy Science, 69 (1986) 4, 1081-1086

ABUBAKAR, B.Y.; MCDOWELL, R.E.; VAN VLECK, L.D.; CABELLOE, E.:

Phenotypic and genetic parameters for Holstein in Mexico. Tropical Agriculture (Trinidad), 64 (1987) $1,23-26$

ABUZAID, A.H.:

Critical study on the performance of exotic dairy cows under Butana Dairy farm conditions in Sudan. M.Sc. Thesis, University of Khartoum.fi, E.A., Khalil, M.H., Sultan, Z.A. 1998. Estimation of genetic parametes and sire values for milk production of Friesian cattle in Egypt. Egyptian Journal of Animal Production 29 (1998) 2, 197-214

AHMED, M-K. A.; KHAROOFA, A.D.S.; SALHAB, S.A.; ZAIED, A.A.:

Comparative performance of imported and homebred Holstein- Friesian cows. El Mukhtar for Agricultural Sciences, 3 (1996), 9-25

AHMED, M.M.M.; EL AMIN, A.I.:

Effect of hot dry summer tropical climate on forage intake and milk yield in Holstein-Friesian and indigenous zebu cows in Sudan.. Journal of Arid Environments, 35 (1997) 4, 737-746

ARAB ORGANIZATION FOR AGRICULTURAL DEVELOPMENT (AOAD): Arab Organization for Agricultural Development Annual Report (2004)

ATIL, H.:

Genetic relationship between days open and days dry with milk yield in a herd of Holstein Friesian cattle. Arch. Tierz., Dummerstorf 43 (2000), 583 - 590

ATIL, H.; KHATTAB, A. S.:

A comparison of different methods of estimating sire transmitting ability of some milk traits in a herd of Holstein-Friesian cattle in Egypt. Arch. Tierz., Dummerstorf, 43 (2000) 2, 115-122

BECKER, W.A.:

Manual of Quantitative Genetics, Washington State University. Press (1975), Pullman, Washington

CHAGUNDA, M. G. G.; BRUNS, E. W.; WOLLNY, C. B. A.; KING, H. M.:

Effect of milk yield-based selection on some reproductive traits of Holstein Friesian cows on largescale dairy farms in Malawi. Livestock Research for Rural Development 16 (2004) 7

CHAGUNDA, M. G.; WOLLNY, C.; NGWERUME, F.; KAMWANJA, L. A.; MAKHAMBERA, T. P. E.:

Environmental factors affecting milk production of a Holstein Friesian herd in southern Malawi. Proceedings of the International Symposium on Livestock Production through Animal Breeding and Genetics. Edited by K. Dzama, F.N. Ngwerume and E. Bhebhe University of Zimbabwe May 10-11, 1995

EL AMIN, F.M.; SIMERL, N.A.; WILCOX, C.J.:

Genetic and environmental effects upon reproductive performance of Holstein crossbreds in the Sudan. Journal of Dairy Science 69 (1986) 4, 1093-1097

GOSHU, G.:

Breeding efficiency, lifetime lactation and calving performance of Friesian -Boran crossbred cows at Cheffa farm, Ethiopia. Livestock Research for Rural Development 17 (7) (2005)

HARVEY, W.R.:

Users guide for LSMLMW and MIXMDL PC-2 version. Ohio State University; 1990. p. 90

HERNANDEZ, M. C.; HEREDIA, E.V.; CORREA, J.C.S.:

Lactation length and milk production of Holsteins cows in Yucatan, Mexico. Rev. Biomed. 13 (2002), 25-31

JUMA, K.H.; AL TIKRITI, S.T.R.:

Performances of Brown Swiss and Friesian cattle in central Iraq. Proceedings of the $4^{\text {th }}$ World Congress of Genetics Applied to Livestock Production, Edinburgh 23-27 July1990

KHATTAB, A. S.; ATIL, H.; BADAWY, L.:

Variances of direct and maternal genetic effects for milk yield and age at first calving in a herd of Friesian cattle in Egypt. Arch Tierz., Dummerstorf 48 (2005) 1, 24-31

KUNAKA, K.; MAKUZA, S.; WOLLNY, C.B.A.; BANDA, J.W.: 
Genetic trends for milk, fat and protein in the Zimbabwean Holstein Friesian population from 1973 1994. Arch. Tierz., Dummerstorf 44 (2001), 23 - 31

MBAP,S.T.; NGERE, L.O.:

Productivity of Friesian cattle in a subtropical environment. Tropical Journal of Agriculture (Trinidad) 66 (1989) 2, 121-124

MOHSEN, M.K.; TAWFIK, E.S.; SALEM, A.Y.; EL-AWADY, H.G.:

Study on Friesian herds raised in Egypt and Germany. II.: genetic and phenotypic trends in estimated transmitting ability. Arch. Tierz., Dummerstorf 43 (2000), 399 - 410

MUSA, L.M-A.; AHMED, M-K.A.; PETERS, K.J.; ZUMBACH, B.; GUBARTALLA, K.A.E.:

The reproductive and milk performance merit of Butana cattle in Sudan. Arch. Tierz., Dummerstorf 48 (2005), 445 - 459

OJANGO, J.M.K.; POLLOTT, G.E.:

Genetic of milk yield and fertility traits in Holstein-Friesian cattle on large-scale Kenyan farms. J. Anim. Sci. 79 (2001), 1742-1750

OJANGO, J.M.K.; POLLOTT, G.E.:

The relationship between Holstein bull breeding values for milk yield derived in both the UK and Kenya. Livestock Production Science 74 (2002), 1 - 12

REGE, J.E.O.:

Genetic analysis of reproductive and productive performance of Friesian cattle in Kenya. I. Genetic and phenotypic parameters. J. Anim. Breeding Genet. 108 (1991), 412-423

SAEED, A.M.; WARD, P.N.; LIGHT, D.; DURKIN, J.W.; WILSON, R.T.:

Characterization of Kenana cattle at Umbenein. Sudan. ILRI Research Report No. 16 (1987), Addis Ababa, Ethiopia

SALAH, M.S.; MOGAWER, H.H.:

Reproductive performance of Friesian cows in Saudi Arabia. II. Resting and service interval, conception rate, and number of services per conception. Beitr. Trop. Landwirtsch. Veterinärmed. 28 (1990) 1, 85-91

TADESSE, M.. DESSIE, T.:

Milk performance of zebu, Holstein Friesian and their crosses in Ethiopia. Livestock Research for Rural Development 3 (2003) 15

TAHIR, K.N.; MAAROF, N.N.:

Studies on the performance of Friesian cattle in Iraq. III. Service period and calving interval. ZANCO. 6 (1988) 4, 41-47

TAWFIK, E.S.; MOHSEN, M.K.; SALEM, A.Y.; EL-AWADY, H.G.:

Study on Friesian herds raised in Egypt and Germany. I. Estimate of non genetic effects and genetic parameters. Arch. Tierz., Dummerstorf 43 (2000), 101 - 114

WOLLNY, C.B.A.; NAMWAZA, A.G.; MAKAMBA, T.S.W.; KUETTNER, K.:

Zum Stand der Rinderzucht in Malawi. Arch. Tierz., Dummerstorf 41 (1998) 2, 33 - 44

Received: 2006-09-18

Accepted: 2006-12-07

Corresponding Author

Prof. Dr. KURT J. PETERS

Department of Animal Breeding and Aquaculture

in the Tropics and Subtropics,

Faculty of Agriculture and Horticulture,

Humboldt-University Berlin,

Philippstr. 13, Haus 9

10115 BERLIN, GERMANY

E-Mail: k.peters@agrar.hu-berlin.de 